\title{
Norm Transfer in US Technology Transfer: A Lesson for Policy Makers
}

\author{
Chris J. Barton ${ }^{*}$, Catherine P. Slade ${ }^{2}$, Derrick M. Anderson ${ }^{3}$
}

\begin{abstract}
Social norms wield significant influence in public policy development. This paper offers a description of four norms that influence technology transfer within and between US institutions. These norms are located within the three environments of the US policy system: policy formation, policy implementation, and policy evaluation. Introducing the concept of 'norm transfer', we argue that norms cannot be assumed to permeate the entire policy system and that some prominent norms are in fact influential only in one or two of the policy environments. We demonstrate this idea using the case of technology transfer in the US, and suggest that understanding the role of norms in technology transfer is essential for improving the ability of universities and research labs to serve the public good. Our intention is to help policy makers better understand the influence of norms in the process of designing policy.
\end{abstract}

Keywords: Technology Transfer; Norms; US Science and Technology Policy; Norm Transfer

Submitted: July $26^{\text {th }}, 2021 /$ Approved: October $26^{\text {th }}, 2021$

\section{Introduction}

Research universities and federal laboratories in the United States are expected to serve the public good. Historically, they are understood to have done so by producing new knowledge through speculative academic inquiry and by resolving societal problems through science and technology (Calhoun, 2006; Marginson, 2011). In recent decades, however, these institutions have been understood to serve the public by commercializing the knowledge they produce, aspiring to "immediate, measurable market acceptance for outputs of academic research" (Perkmann et al., 2013, p. 423). Universities and federal laboratories are expected to serve the public by transforming basic research into technologies with measurable economic impact (Dart, 2004; Metlay, 2006; Sanders \& Miller, 2010; Schacht, 2012). This process of commercializing academic science, referred to as technology transfer, has become an important component of the US innovation system, and an ongoing area of interest for public policy and management (Bercovitz \& Feldman, 2006; Bozeman, 2000). A similar process has occurred in other countries as well (Necoechea-Mondragón, Pineda-Domínguez, \& Soto-Flores, 2013; Srivastava \& Chandra, 2012).

This paper discusses social norms - influential 'ought-propositions' that inform people's thinking (MacCormick, 1998, p. 303) - relevant to technology transfer policy and management in the United States. Norms wield significant influence in public policy development, but they can also be counterproductive and misleading (Cialdini \& Trost, 1998). Improving any area of policy and management (including, but not limited to, technology transfer) involves understanding which norms are influential in which policy areas and how they both enable and constrain the ways we think and act. Understanding the influence of norms on the US technology transfer system can help policy makers understand why the system is structured the way it is as well as how to improve it. This paper proposes a framework of "norm transfer," or the degree to which a specific norm's influence translates between domains of policy and management. We suggest that understanding the role of norms in technology transfer is essential for improving the ability of universities and research labs to serve the public good (Dart, 2004; Kerlin, 2006).

We begin with a discussion of the role of norms in public policy and management and introduce the concept of norm transfer. Next, we give an overview of the history of technology transfer in the US. Finally, we describe a framework of four notable norms that inform US federal technology transfer management and policy: the norms of market impact, sector/size difference, sociotechnical human capital, and public value. We identify two of these norms as transferred (market impact and sector/size difference) and two as pre-transfer (sociotechnical human capital and public value). Our objective is not to provide an exhaustive analysis of the norms that influence technology transfer in the US - an immense, if not impossible, task - but rather to identify a handful of prominent norms and use these to demonstrate the utility of the concept of norm transfer.

\section{Norms in Technology Transfer Policy and Management}

The US federal government spends more than $\$ 140$ billion on research and development $(\mathrm{R} \& \mathrm{D})$ each year, much of which is carried out by universities and federal laboratories (Hourihan \& Parkes, 2017). This investment is justified in terms of the prospects for developing technologies that can be transferred to private or commercial use (Schacht, 2012). Successful transfer of federally funded research has led to the creation of several significant technologies, including the Internet, the smartphone, and Global Positioning Systems (Mazzucato, 2015), and continues to produce innovations in everything from DNA diagnostic tools to fluorescent lighting (U.S. DOE Office of Science, 2020).

Early forms of technology transfer involved informal sharing of information and diffusion of human capital through professional networks, a practice that continues today (Bozeman \& Youtie, 2017a).

(1) School for the Future of Innovation in Society, Arizona State University

(2) James M. Hull College of Business, Augusta University

(3) School of Public Affairs, Arizona State University

*Corresponding author: cjbarton@tbird.asu.edu 
Technology transfer as a distinct field emerged in the years following World War II (Sampat, 2006), with the 1980 passage of the Bayh-Dole Act serving as a major affirmation of its importance. Since passage of Bayh-Dole, technology transfer has become an increasingly formal and bureaucratic process. Universities and government laboratories now have offices of technology transfer (OTTs), and assorted metrics have been developed to define the expected outcomes of these offices (Bozeman, 2000; Cummings \& Teng, 2003).

Technology transfer has been studied through many disciplinary lenses. Organizational theorists have examined the ways in which university offices of technology transfer have evolved to promote new firm creation as the primary mode of technology transfer and regional economic development (Heinonen, 2015; Rothaermel, Agung, \& Jiang, 2007; Siegel, Veugelers, \& Wright, 2007). Public policy scholars have studied how governments guide the ways universities and federal labs move discoveries into the private sector (O'shea, Allen, Chevalier, \& Roche, 2005; Storey \& Tether, 1998). In management, scholars have examined relationships between university faculty productivity and involvement in technology transfer (Agrawal \& Henderson, 2002), how firms approach technology transfer versus internal R\&D (Park \& Lee, 2011), and the mediating effects of established relationships between technology buyers and sellers in determining the success of a transfer (Kotabe, Martin, \& Domoto, 2003). Economists have divided technological development into stages of invention, innovation and diffusion to analyze the ways in which technology boosts economic development (Görg \& Greenaway, 2004; Stoneman \& Diederen, 1994). And finally, sociologists of science have examined how increased focus on technology transfer and economic development has changed the structure of university research and the relationships between universities and industry (Mowery, Nelson, Sampat, \& Ziedonis, 2001; Sanders \& Miller, 2010; Wright, 2014). Underlying these disciplinary perspectives is considerable common ground, including the notion that human thoughts and behaviors are informed, in part, by normative views about how individuals, groups, systems and institutions should work.

Connecting all disciplines noted above is the notion that thoughts and behaviors are informed, in part, by normative views about how individuals, groups, systems and institutions should work. Following MacCormick (1998, 303), we offer 'norm' to be "a general catch-all term to cover any explicit or implicit 'ought-proposition' that is supposed to [inform] judgment in somebody's practical thought." This resonates with new institutional theory (DiMaggio \& Powell, 1983, 1991), which accounts for the change within public institutions over time, where heterogeneous actors in each institution become more homogenous in practice (Zucker, 1988).

Although they often serve a social function, norms are not always helpful for achieving specific aims (Cialdini \& Trost, 1998). Regardless of their accuracy or utility, however, norms lead to common or coordinated action, and can exist as formal rules, information conventions, or anywhere in between (MacCormick, 1998). As shown below, some norms are helpful in coordinating technology transfer, while others perpetuate misunderstandings of the technology transfer process.
Our analysis of norms in technology transfer is informed by Nakamura and Smallwood's 1980 book "The Politics of Policy Implementation," where the authors identify three "environments" that comprise the policy system: policy formation, policy implementation, and policy evaluation. The policy environments are functional domains that contain "a variety of actors and arenas, each of which is connected to the others by various communications and compliance linkages" (Nakamura \& Smallwood, 1980, p. 27). This conceptualization the policy system (rather than the policy process) informs our understanding of the relationship between norms and policymaking. It allows for understanding policymakers, administrators, and evaluators as cultural groups influenced by norms and institutional pressures rather than as purely mechanical components of a policy 'machine' (Nakamura \& Smallwood, 1980, p. 11).

Each environment operates as a separate social and institutional domain; therefore, norms are not equally influential across all three policy environments. Transfer of norms relies on "communications and compliance linkages," which transfer both factual and cultural information. Nakamura and Smallwood suggest three sources of communication breakdowns:

"1) Garbled messages from the senders, 2) misinterpretations by the receivers, 3) system failure in terms of transmission breakdowns, overload, "noise," and inadequate follow-though or compliance mechanisms” (1980, 24).

To this list we add Sanders and Miller's (2010, p. 690) insight that transmission of norms between technology transfer domains is always partial and contested, and that norms are often re-interpreted and reframed when adopted by new actors. For these reasons and more, norms present in one environment cannot be assumed to be present in other environments.

The literature shows that technology transfer is a coordinated (albeit messy) process. Some norms do seem to inform policy priorities, management practices, and evaluation regimes, meaning they have been successfully transferred between the policy environments. We term these transferred norms. Other norms are easily identified in one or two environments but are absent or muted in the others. We term these pre-transfer norms.

We suggest that technology transfer policies and practices are necessarily shaped by normative views about how the development of technology should function. These norms are expressed and operationalized in one or more domains of policy work. There are many norms at work in technology transfer, and their relative influence changes depending on time, location, and culture, as well as individual, professional, and institutional context (Sanders \& Miller, 2010). While acknowledging that the norms which influence technology transfer are myriad and constantly in flux, we identify four which are notable for their substantial presence in the academic literature and policy documents related to technology transfer. Table 1 describes these four norms.

Of the four norms we have identified, two can be described as transferred - the market impact norm and the sector/size difference norm. 
The remaining two - the sociotechnical human capital and public values norms - can be described as pre-transfer. We describe each of these norms in detail below, following a short introduction to the history of technology transfer in the US.

Figure 1: The presence of norms across policy environments in US technology transfer

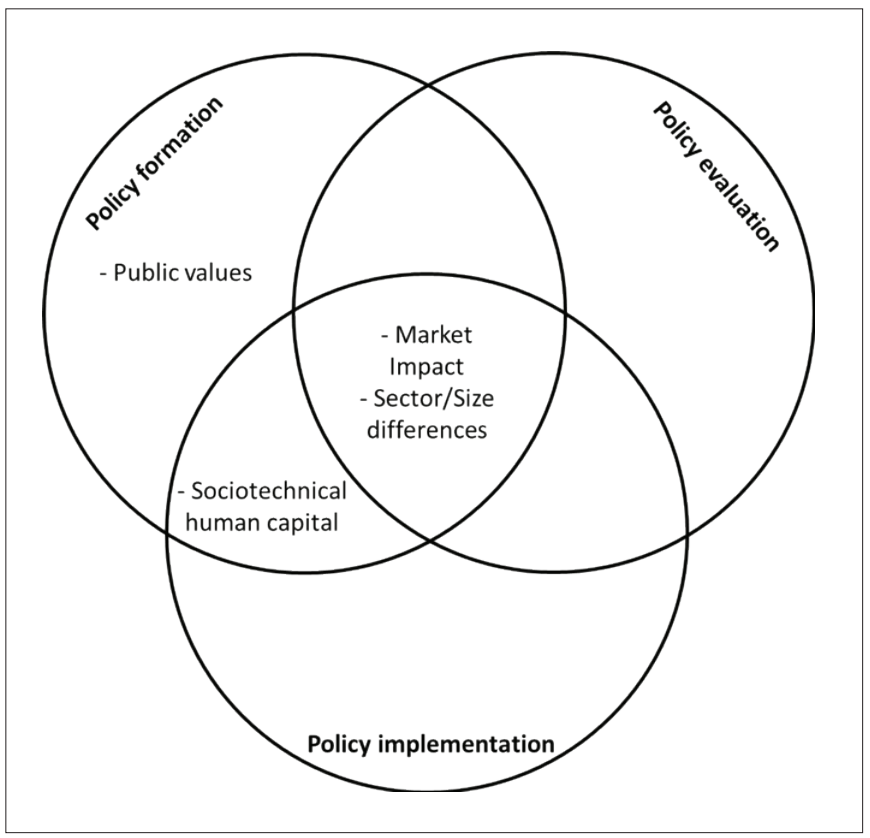

\section{Background of US Technology Transfer}

Technology transfer provides a case study of how norm transfer within public policy can shape the growth of an industry. Vannevar Bush, directing the Office of Scientific Research and Development during WWII and laid the groundwork for the post-war national innovation system, proposing that federally funded research in the years following WWII could be instrumental for economic development (Bush, 1945). With onset of the Cold War, national security interests replaced economic development considerations as the primary motive for public investment in science (Leslie, 1993).

The late 1970s saw a deep recession and growing concern among policymakers that American industries were being out-performed in terms of innovation and productivity by foreign markets (Hill, Hitt, \& Hoskisson, 1988; Papadakis, 1994). By 1980 legislative solutions emerged with lasting effects on how and why institutions, organizations and individuals would go about the work of technology transfer. The Bayh-Dole Act streamlined and simplified the process for institutions receiving federal R\&D funding; and allowed them to own intellectual property developed through that research (Kenney \& Patton, 2009). The Stevenson-Wydler Act of 1980, a legislative compliment to Bayh-Dole, mandated that government laboratories place an administrative emphasis on technology commercialization (StevensonWydler Technology Innovation Act of 1980). The Federal Technology Transfer Act of 1986 (FTTA) allowed federal agencies to enter cooperative research and development agreements (CRADA) and negotiate licensing agreements with private sector partners (FTTA 1986). The FTTA also allowed government researchers to receive a share of the royalties when their inventions were licensed (Winebrake, 1992). Individual researchers were incentivized to collaborate with private sector partners and to invest the time necessary to ensure that the technologies they developed were fully understood by (i.e. transferred to) private sector partners (Link, Siegel, \& Van Fleet, 2011).

Much of the $20^{\text {th }}$ century focused on patenting and licensing in universities and new discoveries were rare (Sampat, 2006). Instead, technology transfer involved informal mechanisms such as joint publication with industry scientists and industrial consulting (Link, Siegel, \& Bozeman, 2017; Link et al., 2011). Federal and university laboratories engaged mainly with large firms (Kenney \& Patton, 2009). Unless they could work directly with inventors, most firms did not take advantage of university resources (U.S. Dept. of Health and Human Services [DHHS], Office of Inspector General, 1993).

Passage of Bayh-Dole, Stevenson-Wydler, and the FTTA arguably initiated a new paradigm for technology transfer in the United States. The policies inaugurated a professionalization of the technology transfer field (Link et al., 2011; Mowery et al., 2001), and signaled to the private sector that the government was willing to collaborate. As a result, collaborations between public-sector researchers and private firms have increased steadily (National Science Foundation, 2014).

University research centers and federal research labs are critical actors in federal technology transfer (Bozeman, 2000). They receive significant federal funding and are relatively insulated from the risk of market failure faced by private firms. , Universities and federal labs are therefore able to pursue basic and applied research in high-risk areas (Bozeman \& Boardman, 2003). Thus, technology transfer activities at universities and federal labs have grown since the 1980s (Geiger, 2012). Most, if not all, federal labs and major research universities now have offices dedicated to coordinating technology transfer and industry engagement.

Both labs and universities tend to emphasize applied fields such as medicine and engineering over more basic research fields such as physics and chemistry (Crow \& Bozeman, 1998). While similar in this regard, other factors differentiate these organizations. Federal labs have substantial resources for technical equipment and are able to organize research around problems rather than disciplines (Bozeman, 2000). This makes federal labs attractive for cooperative research and development agreements (CRADA), where private sector scientists gain access to federal lab resources for specific projects (Rogers, Carayannis, Kurihara, \& Allbritton, 1998). The primary advantage of universities is the presence of students (Bozeman, 2000), who offer inexpensive labor and a specialized talent pool. The "transfer" of a university graduate into a firm's workforce expands the firm's knowledge network and constitutes a technology transfer success (Bercovitz \& Feldman, 2006). Many firms are expanding funding for university research in order to promote basic research which otherwise faces defunding (Hall, Link, \& Scott, 2003), and also to tap into potential talent pools. 
Federal labs have long been successful at transferring technology. For example, NASA's 1958 enabling legislation required the agency to engage in technology transfer (NASA, 1998). The Department of Agriculture (USDA) has been transferring technological goods for more than a century, beginning with the establishment of the land grant colleges under the Morrill Act in 1862 and expanded by the Hatch Act of 1887, which created agricultural research stations separate from the university sys- tem (Agricultural Research Service, 2011; Duties of Secretary; Ascertainment of Entitlement of State to Funds; Plans of Work, 2015). The goals of these laws were to educate farmers and provide them with the latest research in order to increase agricultural productivity (Hornig, 1984). The USDA's Agricultural Research and Extension Services have become one of the most successful technology transfer programs in the federal government (Agricultural Research Service, 2011).

\section{Norms in Technology Transfer Policy}

Table 1: Norms of technology transfer management and policy

\begin{tabular}{|c|c|c|c|c|}
\hline Norms & Description & Policy Formation example & Implementation Example & Evaluation Example \\
\hline Market impact norm & $\begin{array}{l}\text { Tech transfer policy is dis- } \\
\text { cussed and justified in terms } \\
\text { of market impact, including } \\
\text { economic competitiveness and } \\
\text { commercialization. }\end{array}$ & $\begin{array}{l}\text { The primary "civilian use" } \\
\text { for reallocated defense } \\
\text { resources proposed by Office } \\
\text { of Technology Assessment } \\
\text { was civilian technology } \\
\text { development in private in- } \\
\text { dustry (Office of Technology } \\
\text { Assessment, US Congress, } \\
\text { 1993b, p. iii) }\end{array}$ & $\begin{array}{l}\text { The "Startup America" ini- } \\
\text { tiative was created with the } \\
\text { goal of increasing startups } \\
\text { based on technologically } \\
\text { transferred from federal labs } \\
\text { (U.S. White House, Office } \\
\text { of the Press Secretary, 2011). }\end{array}$ & $\begin{array}{l}\text { Each year, federal agencies report on } \\
\text { both the raw number and monetary } \\
\text { reward from patents and licenses } \\
\text { generated based on technology } \\
\text { developed in their labs. } \\
\text { (Stevenson-Wydler Technology } \\
\text { Innovation Act of 1980, 1980, p. 17) }\end{array}$ \\
\hline $\begin{array}{l}\text { Sector/Size differences } \\
\text { norm }\end{array}$ & $\begin{array}{l}\text { The role of an organization in } \\
\text { technology transfer is limited } \\
\text { by its sector and by its size. }\end{array}$ & $\begin{array}{l}\text { A } 2010 \text { House Resolution } \\
\text { states, "The commercial } \\
\text { development of discoveries } \\
\text { and inventions falls upon } \\
\text { private sector entrepreneurs" } \\
\text { (H. CON. RES. 328, 2010) } \\
\text { Legislation such as the Bayh- } \\
\text { Dole and Stevenson-Wydler } \\
\text { Acts were created with the } \\
\text { goal of transferring more } \\
\text { technology developed in } \\
\text { the public sector to private } \\
\text { industry, rather than directly } \\
\text { commercializing technology } \\
\text { through the agency that } \\
\text { developed it (Sampat, 2006). }\end{array}$ & $\begin{array}{l}\text { The concept of absorptive } \\
\text { capacity dictates that small } \\
\text { firms are less able to receive } \\
\text { technology transfers than } \\
\text { large firms. (De Jong \& } \\
\text { Freel, 2010) } \\
\text { In 'model' tech hubs such } \\
\text { as silicon valley, tech is } \\
\text { understood to be develo- } \\
\text { ped at universities (such as } \\
\text { Stanford) and then passed } \\
\text { to industry. } \\
\text { (Díez-Vial \& Fernández- } \\
\text { Olmos, 2015) }\end{array}$ & $\begin{array}{l}\text { Technology transfer success for } \\
\text { universities and federal labs is eva- } \\
\text { luated based on patents and licenses } \\
\text { (Stevenson-Wydler Technology } \\
\text { Innovation Act of 1980, 1980, p. } \\
\text { 17), while for private companies it is } \\
\text { based on profit. }\end{array}$ \\
\hline $\begin{array}{l}\text { Sociotechnical human } \\
\text { capital norm }\end{array}$ & $\begin{array}{l}\text { The success of a technology } \\
\text { transfer process is tied to the } \\
\text { sociotechnical capacity of } \\
\text { the people and communities } \\
\text { involved. }\end{array}$ & $\begin{array}{l}\text { The NSF 'Innovation Corps' } \\
\text { aims to "reduce the time and } \\
\text { risk associated with trans- } \\
\text { lating promising ideas and } \\
\text { technologies from the labo- } \\
\text { ratory to the marketplace" } \\
\text { by training researchers on } \\
\text { how to commercialize their } \\
\text { research (National Science } \\
\text { Foundation, 2020) }\end{array}$ & $\begin{array}{l}\text { Employees of startups which } \\
\text { receive technology transfers } \\
\text { are considered valuable even } \\
\text { if the startup fails. } \\
\text { (Horrell \& Litan, 2010) } \\
\text { Tech transfer success in } \\
\text { successful tech hubs is } \\
\text { dependent on local socio- } \\
\text { technical human capital and } \\
\text { the systems that attract and } \\
\text { foster it (Carr, 1994; Ough- } \\
\text { ton, Landabaso, \& Morgan, } \\
\text { 2002). }\end{array}$ & \\
\hline Public values norm & $\begin{array}{l}\text { Government programs and } \\
\text { policies - including those } \\
\text { regarding technology transfer } \\
\text { - should be driven by concerns } \\
\text { for the common good and pu- } \\
\text { blic interest above and beyond } \\
\text { individual economic interests }\end{array}$ & $\begin{array}{l}\text { Public universities and } \\
\text { federal labs are motivated, } \\
\text { influenced, and directed } \\
\text { by public value goals. } \\
\text { (Bozeman, Rimes, \& Youtie, } \\
\text { 2015a) }\end{array}$ & & \\
\hline
\end{tabular}


Transferred Norms: Market Impact and Sector/Size Difference

These norms are present in all three policy environments.

The market impact norm.

The market impact norm dictates that tech transfer policy is discussed and justified in terms of market impact, including economic competitiveness and commercialization.

This is a recent development. Most federal labs were established in the wake of WWII and experienced rapid growth during the Cold War. Although Vannevar Bush proposed a role for federal labs in economic development as early as 1945 (Bush, 1945), they were created and designed primarily for national defense purposes with the US government as their main client (Mowery, Nelson, Sampat, \& Ziedonis, 2015). After the fall of the Soviet Union, the federal lab system became less focused on defense (Adams, Chiang, \& Jensen, 2003). The 1980s were marked by growing concern that US firms were unable to compete in rapidly evolving international markets, leading policymakers to take the potential role of federal labs in economic development more seriously (Bozeman \& Boardman, 2003). Experts worried that basic knowledge developed through public investment in the United States was being maximized for economic gains by foreign nations rather than American firms (Rahm, Bozeman, \& Crow, 1988). This concern animated a shift in the discourse around technology transfer from public labs and universities. Technology transfer is now discussed as a driver of economic development, job growth, and enhancement of the global economic competitiveness of the United States (Friedman \& Silberman, 2003; Teece, 1977). In this way the market impact informs policy formation.

The market impact norm and the focus on using federally funded research to fuel economic growth informs policy implementation as well. For example, a 2011 memorandum from President Obama praised technology transfer as a way to boost competitiveness and increase the societal impact of technologies developed in federal research labs. Here, Obama uses market impact as a normative justification for an administrative policy (U.S. White House, Office of the Press Secretary, 2011):

"Innovation fuels economic growth, the creation of new industries, companies, jobs, products and services, and the global competitiveness of U.S. industries.... One of the goals of my Administration...is to foster innovation by increasing the rate of technology transfer and the economic and societal impact from federal research and development (R\&D) investments."

However, this norm is most influential in the evaluation environment, where the metrics used to determine the effectiveness of technology transfer focus mainly on market impact via commercialization. The success or failure of a technology transfer process depends on the complex relationship between government regulation, marketing, collaboration between government or university labs and industry labs, and the enthusiasm with which the company developing the technology pursues it. Commercialization is a problematic way to measure success. This is an instance where the norm is misleading and, arguably, counterproductive.
As the federal government invested in technology transfer, metrics were needed to ensure that resources where being allocated effectively (Lundquist, 2003; Rogers, Takegami, \& Yin, 2001). However, what constitutes a technology transfer is not well-defined, making it difficult to measure transfer success. So called 'out-the-door' metrics are commonly used in technology transfer (Bozeman, Rimes, \& Youtie, $2015 b$, p. 37). These types of metrics count the moment of transfer as success (Bercovitz \& Feldman, 2006), measuring things such as the number of patents filed and received, license agreements executed, or CRADAs initiated (Bozeman et al., 2015b).

The out-the-door model has evolved over several decades along three main paths. In the early 2000s, many researchers simply assumed that increased use of transfer mechanisms led to positive market impact, and thus focused on how best to increase the number of patents or CRADA (Jaffe \& Lerner, 2001). The analyses did not track outcomes following the moment of transfer to a firm, making it difficult to determine the impact of the transfer. The second outthe-door model analyzes only impacts on the transferring agent, such as federal ORTAs or university OTTs, in the form of licensing revenues (Adams et al., 2003). When technology is transferred, the originating laboratory often obtains some amount of revenue such as royalties from patenting, or cost-sharing with CRADA partners. While not a direct measure of overall market impact, licensing revenue is one potential indicator of impact beyond the initial transfer (Bozeman, 2013). The third out-the-door model considers impact on the transfer recipient. While this model does have larger scope than the previous models, it is still focused on commercialization and does not take into account social and broader economic impact (Powers, 2003).

\section{The Sector/Size Difference Norm.}

The sector/size difference norm suggests that the role of an organization in technology transfer is limited by its sector and by its size. This norm suggests that public and private organizations have fundamentally different roles in technology transfer, and that an organization's capacity to participate in tech transfer is limited by its size.

Organization studies is often concerned with understanding differences between public and private organizations. For example, scholars have examined goal complexity in public organizations (Anderson \& Stritch, 2015; Rainey \& Bozeman, 2000), and how organizational structure and goal clarity of private firms can lead to certain forms of public value failure (Anderson \& Taggart, 2016). While the relationship between public and private organizations is complex, there are many domains of social enterprise that operate according to stylized assumptions of what public and private organizations do and do not do well (Rainey \& Bozeman, 2000). Technology transfer is one such domain. Private firms are considered suboptimal for the production of basic research because the distance between basic research and commercialization is considered too great for private firms to take the risk. However, they are thought to be better than the public sector at developing knowledge into commercial goods. 
Policy formation has been influenced by this norm. A 2010 House Resolution states, "The commercial development of discoveries and inventions falls upon private sector entrepreneurs" (H. CON. RES. 328, 2010, p. 2). A 2013 Brookings Institute report declares that "the private sector is needed to develop and take to scale new patterns of sustainable production" (Brookings Institution, 2013, p. 3).

Sector roles in the implementation of technology transfer policy are focused on the benefits of scale (i.e. size) in private corporations. Throughout the 1980's, many believed that access to quality information was the limiting factor for technology transfer in small and medium scale enterprises (Glass \& Saggi, 1998). Cohen and Levinthal introduced the concept of "absorptive capacity," defined as a "firm's ability to recognize the value of new, external information, assimilate it, and apply it to commercial ends" (1990, pp. 128-129). de Jong and Freel find that "to the extent that the development of current knowledge requires resources, resource constrained small firms are likely to have both a narrower and shallower absorptive capacity than their larger peers" (2010, p. 48).

This thinking influences the implementation of tech transfer policy by defining which organizations (public/private, large/small) are expected to develop and commercialize technology. For example, science and technology hubs such as Silicon Valley are based on a model where universities develop new technology which is then commercialized by local industry (Díez-Vial \& Fernández-Olmos, 2015). Many firms embrace this logic as well. Small firms tend to have little human capital dedicated to $\mathrm{R} \& \mathrm{D}$, compared to large corporations. A majority of SMEs do not have an in-house research unit, despite evidence that even a single employee dedicated to R\&D greatly increases absorptive capacity (Griffith, Redding, \& Van Reenen, 2003). In-house R\&D allows firms to assess the merits of new technologies and improve the chances of transfer success (Audretsch et al., 2002). This ability to adapt and develop new technology is considered critical to firm survival, but is present mainly in large firms (Curran, Blackburn, Kitching, \& North, 1996; Gray, 2003).

Finally, the sector/size difference norm's influence in policy evaluation is clear: For private firms, success is evaluated based on profit; but for universities and federal labs success is evaluated based on patents and licenses (Stevenson-Wydler Technology Innovation Act of 1980, 1980, p. 17).

This norm, like the market impact norm discussed in the previous section, can be misleading. The absence of an imperative to maximize profit does deprive the public sector of a strong incentive to commercialize technology - but public organizations have nonetheless shown a robust capability to fully develop new technologies and usher them toward end uses. Technologies created for national defense purposes demonstrate the misleading nature of this norm. The Internet (National Research Council, 1999), Global Positioning Systems, and voice activation technology (Mazzucato, 2015), were fully developed, transferred, and used effectively within public organizations before eventually being commercialized.

\section{Pre-transferred norms: Sociotechnical human capital and public values}

We discuss below the two norms we have identified as significantly influential in only one or two policy environments. However, these norms are likely present in a nascent form across the entire policy system.

\section{Sociotechnical human capital norm.}

This norm posits that the success of a technology transfer process is tied to the sociotechnical capacity of the people and communities involved.

Sociotechnical human capital theory predicts the impact of humantechnology interactions on institutions (Resnick, 2001). Technology transfer can be conceptualized as a process of human capital development and knowledge network expansion. In this view, technology transfer is a dynamic system with various feedback loops between several actors (Libecap, Thursby, \& Hoskinson, 2010). The technological product cannot be transferred entirely without close interaction between inventors and manufacturers (Lin \& Bozeman, 2006). Descriptions, research samples, or working prototypes rarely convey all the information that is needed in order to produce a successful product (Saavedra \& Bozeman, 2004). Tacit knowledge, ideas, and suggestions among research collaborators are often extremely valuable information (Bozeman, Fay, \& Slade, 2013), despite being more difficult to measure than a patent or license agreement. The enhanced social and human capital of the innovation network which results from these informal exchanges not only facilitates successful transfer of current technologies, but also becomes the cornerstone of future technological innovations.

US startup tech companies are excellent examples of the way the human capital knowledge networks work in practice. These companies have a high failure rate, which would seem to indicate a deep flaw in the technology transfer and development system. However, many former employees of failed startups are hired by other startups in the same cohort or by older, established firms (Horrell \& Litan, 2010). This suggests that even though employees in failing firms might be displaced in their first year, the skills and experience acquired on the job make them desirable hires for more competitive companies.

Another example involves successful regional innovation hubs such as California's Silicon Valley or Route 128 in Massachusetts, both of which are integrated with local research universities (Stanford and MIT, respectively). The success of tech transfer at a university or federal lab is often highly dependent on the cultural, historical and environmental context of the transferring organizations (Breznitz \& Feldman, 2012). Research that takes place at the heart of these major tech hubs, which are deeply enmeshed in regional knowledge networks, has many advantages when it comes to technology transfer (Díez-Vial \& Fernández-Olmos, 2015). Companies that are eager to adopt new technologies already exist, and a vibrant entrepreneurial culture means there is no shortage of potential transfer recipients. These examples represent the wide-spread influence of this norm in technology transfer policy implementation. 
There are some indications that this norm is starting to make inroads in the policy formation domain as well. One example of this is the National Science Foundation's Innovation Corps, which "uses experiential education to help researchers gain valuable insight into entrepreneurship, starting a business or industry requirements and challenges" (National Science Foundation, 2020). This program seeks to infuse researchers with the sociotechnical capacity necessary for effective tech transfer, so that they may transfer and commercialize the technology on their own (or as part of a team). Researchers are trained in Stanford University's Lean Launchpad entrepreneurship curriculum and are paired with mentor who has experience transferring academic research into the commercial market (Youtie \& Shapira, 2017).

Although the sociotechnical human capital norm is widely recognized in the implementation domain of tech transfer and is beginning to be influential in the policy formation domain, it is not yet influential in the evaluation domain. This norm may be resisted in policy evaluation because it contradicts the market impact norm. Highlighting the importance of human capital reveals the shortcomings of a simple count of transfer instances as a metric for determining success.

\section{Public value norm.}

The public values norm suggests that government programs and policies - including those regarding technology transfer - should be driven by concerns for the common good and public interest above and beyond individual economic interests (Bozeman, 2007; Bozeman \& Youtie, 2017b).

Although technology transfer programs are frequently evaluated along a narrow set of economic metrics (Sorensen \& Chambers, 2008), the federal government typically justifies investments in science by invoking a broader range of public values (Bozeman et al., 2015b). This suggests that this norm is present in the policy formation environment but has not yet transferred to the policy implementation or evaluation domains.

The problem with this contradiction is twofold. First, many government $R \& D$ programs have complex missions that include development and transfer of technology for national defense, public health, and other non-commercial purposes (Bozeman et al., $2015 b)$. Second, the transfer process includes transmission of specialized knowledge and skills as well as technologies. Job and startup based measures used to evaluate government technology transfer programs often fail to capture these types of benefits (Bozeman et al., 2015b). While President Obama's 2011 memorandum on technology transfer included a broad range of ambitious goals such as improving human health, addressing global climate change, and ensuring the security of the nation, performance in the technology transfer domain was still understood as measurable by "invention disclosures, licenses issued on existing patents, Cooperative Research and Development Agreements (CRADAs)... and successful self-sustaining spinoff companies" (U.S. White House, Office of the Press Secretary, 2011, pp. 1-2).

\section{Discussion}

Technology transfer, like many domains of public management and policy, is an enterprise of political, organizational, managerial, and economic significance. The norms that shape how technology transfer is justified, carried out and evaluated are complex, myriad and changing. We have provided here an account of four influential norms in US technology transfer, cognizant that a comprehensive account of norms in technology transfer is beyond the scope of this exercise. The case of technology transfer is useful for demonstrating the fact that there is no single way that norms operate in the context of public policy and management. We attempt to capture one aspect of this diversity with our proposed concept of "norm transfer." We believe that tracing the diffusion of norms across policy environments can lead to a deeper understanding of the role that norms play in the complex domains of public policy and management.

Although our work focuses on the US system, the dynamics of norm transfer are likely present in other policy environments as well. For example, (Heinonen, 2015) work on a technology transfer process in Finland demonstrates elements of both the market impact and sociotechnical human capital norms. The work of (Ortigueira-Sánchez, Stein, Risco-Martínez, \& Ricalde, 2020) on the relationship between absorptive capacity and innovation for SMEs in Peru reflects the influence of the sector/size difference norm. And a thoughtful exploration of technology transfer from pubic universities in Mexico (Necoechea-Mondragón et al., 2013) echoes elements of all four norms mentioned in this paper. Necoechea-Mondragón and colleagues also make the interesting point that "universities in developing countries are not seen as key players in cutting edge innovation or as leaders of industrial commercialization under globalized conditions" (Necoechea-Mondragón et al., 2013, p. 26). This raises question about the boundaries of policy systems and the appropriate unit of analysis for an assessment of technology transfer policy. Future work should explore the role of norm transfer both within and across national borders. A possible example of cross-border (and cross-policy system) norm transfer is the Indian government's passage of a bill in 2008 modeled on the Bayh-Dole act (Srivastava \& Chandra, 2012).

Future work can also advance the norm transfer idea with empirical analysis. Many theories, including new institutionalism (DiMaggio \& Powell, 1991), address the role of norms in public policy and management, but little attention has been paid to the extent to which they operate consistently or inconsistently across multiple domains of action (the one possible exception being Bozeman's (2007) notion of public value failures of value aggregation). The norm transfer framework we propose provides a research agenda going forward. Questions include how norms originate in policy environments, how they transfer between environments, and the tensions that arise when different parts of the policy system are driven by different norms.

One question we do not explore here in depth, but which merits future research, is the question of why some norms transfer while others do not. One potential explanation is that some norms offer more ambiguous guidance than others. The pre-transfer norms identified here 
differ from the transferred norms in that they are informed by a more complex set of assumptions about the underlying value of technology transfer. As a consequence, they offer somewhat ambiguous prescriptions for how to best do the work of technology transfer and provide no simple success criteria. Arguably, this ambiguity can be seen as derivative of a view of technology transfer from a political, rather than economic, view of the enterprise. Public organization scholars have documented the ways in which ambiguity abounds in public organizations' missions and goals (Chun \& Rainey, 2005). Although many of the organizations involved in technology transfer are nongovernmental, they may still operate according to a public mission or purpose (Bozeman, 1987). These non-economic norms are influential in technology transfer policy formation and implementation but, perhaps as a consequence of their ambiguity, are less commonly referenced in evaluative schemes.

Another possible explanation is that adopting some of these norms influences one's ability to adopt others. For example, the market impact norm and the public values norm can be seen as somewhat contradictory. While both can coexist in the literature as policy priorities, adopting one norm to guide management practices or evaluation (say, the market impact norm) may result in a degree of 'path dependency' where it then becomes difficult to integrate another (the public values norm) into already-existing practices. The ways in which the norms come into conflict may partially explain why some transfer and others do not. Exploring how these norms interact when put into practice is also worthy of future research.

Questions about how norms transfer between policy environments and interact in practice are amenable to empirical study and we intend to use pursue these questions in future research on technology transfer using both qualitative and quantitative methods (Phan \& Siegel, 2006).

\section{Conclusion}

We introduce in this paper a framework for norm transfer in public policy, using the case of technology transfer in the US. We offer a descriptive treatment of four norms that influence technology transfer within and between US institutions. We have placed these norms in the context of Nakamura and Smallwood's policy system, which consists of three "environments:" that of policy formation, policy implementation, and policy evaluation.

We argue that norms cannot be assumed to permeate the entire policy system, and that some prominent norms are in fact influential in only one or two policy environments. The concept of 'norm transfer' and its application to this case can inform future research into the role of norms in public policy and management in general, and in the technology transfer field in particular.

\section{Summary}

Publicly funded research is increasingly understood to serve the public good best when commercialized, often in partnership with private companies. This process, called technology transfer, is an increasingly influential element of science and technology policy. Like any activity, technology transfer is influenced by norms, or oughtpropositions which inform people's thinking. But norms cannot be assumed to be universally influential across a policy system; different norms may be cogent in the 'environments' of policy formation, implementation and evaluation.

In this paper we introduce the concept of 'norm transfer' to describe how norms spread across a policy system. We demonstrate this concept by identifying four norms which are influential in parts of the US technology transfer policy system; two are 'transferred' - present in all three policy environments - and two are pre-transferred - present in only one or two of the policy environments.

Our analysis of the role of norms in US technology transfer is useful for policymakers and practitioners working in this area. The concept of 'norm transfer', however, is relevant to all policy domains, and is useful for helping policymakers understand how and why policies get written and enacted, and the diverse ways that norms influence the policy process.

\section{References}

Adams, J. D., Chiang, E. P., \& Jensen, J. L. (2003). The influence of federal laboratory R\&D on industrial research. The Review of Economics and Statistics, 85(4), 1003-1020.

Agrawal, A., \& Henderson, R. (2002). Putting patents in context: Exploring knowledge transfer from MIT. Management Science, 48(1), 44-60.

Agricultural Research Service. (2011). USDA, Agricultural Research Service (ARS): Technology Transfer Program and Formal Links to Economic Development through its Agricultural Technology Innovation Partnership Program (ATIP) (p. 3).

Anderson, D. M., \& Stritch, J. M. (2015). Goal clarity, task significance, and performance: Evidence from a laboratory experiment. Journal of Public Administration Research and Theory, 26(2), 211-225.

Anderson, D. M., \& Taggart, G. (2016). Organizations, policies, and the roots of public value failure: The case of for-profit higher education. Public Administration Review, 76(5), 779-789.

Audretsch, D. B., Bozeman, B., Combs, K. L., Feldman, M., Link, A. N., Siegel, D. S., ... Wessner, C. (2002). The Economics of Science and Technology. The Journal of Technology Transfer, 27(2), 155-203. https://doi.org/10.1023/A:1014382532639

Bercovitz, J., \& Feldman, M. (2006). Entpreprenerial universities and technology transfer: A conceptual framework for understanding knowledge-based economic development. The Journal of Technology Transfer, 31(1), 175-188.

Bozeman, B. (1987). All organizations are public: Bridging public and private organizational theories (1st ed..). San Francisco: Jossey-Bass. 
Bozeman, B. (2000). Technology transfer and public policy: A review of research and theory. Research Policy, 29(4), 627-655. https://doi. org/10.1016/S0048-7333(99)00093-1

Bozeman, B. (2007). Public values and public interest: Counterbalancing economic individualism. Georgetown University Press.

Bozeman, B. (2013). Technology Transfer Research and Evaluation: Implications for Federal Laboratory Practice (p. 101). Retrieved from https://cloviahamilton.blog/wp-content/uploads/2017/11/bozeman2013-technology-transfer-research-and-evaluation.pdf

Bozeman, B., \& Boardman, P. C. (2003). Managing the New Multipurpose, Multidiscipline University Research. IBM Center for the Business of Government.

Bozeman, B., Fay, D., \& Slade, C. P. (2013). Research collaboration in universities and academic entrepreneurship: The-state-of-the-art. The Journal of Technology Transfer, 38(1), 1-67. https://doi.org/10.1007/ s10961-012-9281-8

Bozeman, B., Rimes, H., \& Youtie, J. (2015a). The evolving state-ofthe-art in technology transfer research: Revisiting the contingent effectiveness model. Research Policy, 44(1), 34-49.

Bozeman, B., Rimes, H., \& Youtie, J. (2015b). The evolving state-ofthe-art in technology transfer research: Revisiting the contingent effectiveness model. Research Policy, 44(1), 34-49.

Bozeman, B., \& Youtie, J. (2017a). Socio-economic impacts and public value of government-funded research: Lessons from four US National Science Foundation initiatives. Research Policy.

Bozeman, B., \& Youtie, J. (2017b). Socio-economic impacts and public value of government-funded research: Lessons from four US National

Science Foundation initiatives. Research Policy, 46(8), 1387-1398.

Breznitz, S. M., \& Feldman, M. P. (2012). The engaged university. The Journal of Technology Transfer, 37(2), 139-157.

Brookings Institution. (2013). Enterprising Solutions: The Role of the Private Sector in Eradicating Global Poverty. Retrieved from https:// www.brookings.edu/wp-content/uploads/2016/06/2013-BBR-PolicyBriefs-FINALVERSION-2.pdf

Bush, V. (1945). Science, the endless frontier: A Report to the President by Vannevar Bush, Director of the Office of Scientific Research and Development, July 1945. United States Government Printing Office. Retrieved from United States Government Printing Office website: https://www.nsf.gov/od/lpa/nsf50/vbush1945.htm

Calhoun, C. (2006). The University and the Public Good. Thesis Eleven, 84(1), 7-43. https://doi.org/10.1177/0725513606060516

Carr, R. K. (1994). Doing technology transfer in federal laboratories. In From Lab to Market (pp. 61-87). Springer.
Chun, Y. H., \& Rainey, H. G. (2005). Goal Ambiguity and Organizational Performance in U.S. Federal Agencies. Journal of Public Administration Research and Theory, 15(4), 529-557. https://doi. org/10.1093/jopart/mui030

Cialdini, R. B., \& Trost, M. R. (1998). Social influence: Social norms, conformity and compliance. In The handbook of social psychology, Vols. 1-2, 4th ed (pp. 151-192). New York, NY, US: McGraw-Hill.

Cohen, W. M., \& Levinthal, D. A. (1990). Absorptive capacity: A new perspective on learning and innovation. Administrative Science Quarterly, 35(1), 128-152.

Crow, M., \& Bozeman, B. (1998). Limited by Design (1 edition). New York: Columbia University Press.

Cummings, J. L., \& Teng, B.-S. (2003). Transferring R\&D knowledge: The key factors affecting knowledge transfer success. Journal of Engineering and Technology Management, 20(1-2), 39-68.

Curran, J., Blackburn, R., Kitching, J., \& North, J. (1996). Establishing small firms' training practices, needs, difficulties and use of industry training organisations. HMSO.

Dart, R. (2004). The legitimacy of social enterprise. Nonprofit Management and Leadership, 14(4), 411-424.

De Jong, J. P., \& Freel, M. (2010). Absorptive capacity and the reach of collaboration in high technology small firms. Research Policy, 39(1), 47-54.

Díez-Vial, I., \& Fernández-Olmos, M. (2015). Knowledge spillovers in science and technology parks: How can firms benefit most? The Journal of Technology Transfer, 40(1), 70-84.

DiMaggio, P. J., \& Powell, W. W. (1983). The iron cage revisited: Institutional isomorphism and collective rationality in organizational fields. American Sociological Review, 147-160.

DiMaggio, P. J., \& Powell, W. W. (1991). Introduction. The new institutionalism in organizational analysis. The New Institutionalism in Organizational Analysis, University of Chicago Press, Chicago, IL, 1-38.

Duties of Secretary; ascertainment of entitlement of State to funds; plans of work. , Pub. L. No. 7 U.S.C. $\$ 361 \mathrm{~g}(2015)$.

Federal Technology Transfer Act of 1986 [FTTA]. , Pub. L. No. 15 USC $\$ 3710$ (1986).

Friedman, J., \& Silberman, J. (2003). University technology transfer: Do incentives, management, and location matter? The Journal of Technology Transfer, 28(1), 17-30.

Geiger, R. L. (2012). University supply and corporate demand for academic research. The Journal of Technology Transfer, 37(2), 175-191.

Glass, A. J., \& Saggi, K. (1998). International technology transfer and the technology gap. Journal of Development Economics, 55(2), 369-398. 
Görg, H., \& Greenaway, D. (2004). Much ado about nothing? Do domestic firms really benefit from foreign direct investment? The World Bank Research Observer, 19(2), 171-197.

Gray, C. (2003). Managing the impact of broadband on microfirms and their networks. The European Journal of Teleworking, 9(1), 4-16.

Griffith, R., Redding, S., \& Van Reenen, J. (2003). R\&D and absorptive capacity: Theory and empirical evidence. Scandinavian Journal of Economics, 105(1), 99-118.

\section{H. CON. RES. 328. , Pub. L. No. H. CON. RES. 328 (2010).}

Hall, B. H., Link, A. N., \& Scott, J. T. (2003). Universities as research partners. Review of Economics and Statistics, 85(2), 485-491.

Heinonen, T. (2015). Management of Innovation in Academia: Going beyond Traditional Technology Transfer. Journal of Technology Management \& Innovation, 10(2), 198-210. https://doi.org/10.4067/ S0718-27242015000200014

Hill, C. W., Hitt, M. A., \& Hoskisson, R. E. (1988). Declining US competitiveness: Reflections on a crisis. Academy of Management Perspectives, 2(1), 51-60.

Hornig, D. F. (1984). The role of government in scientific innovation. In J. S. Coles (Ed.), Technological innovation in the '80s (Vol. 55). Englewood Cliffs, NJ: Prentice-Hall.

Horrell, M., \& Litan, R. E. (2010). After inception: How enduring is job creation by startups? Available at SSRN 1657121.

Hourihan, M., \& Parkes, D. (2017). Federal R\&D in the FY 2016 budget: An overview. American Association for the Advancement of Science.

Jaffe, A. B., \& Lerner, J. (2001). Reinventing public R\&D: Patent policy and the commercialization of national laboratory technologies. RAND Journal of Economics, 167-198.

Kenney, M., \& Patton, D. (2009). Reconsidering the Bayh-Dole Act and the current university invention ownership model. Research Policy, 38(9), 1407-1422.

Kerlin, J. A. (2006). Social Enterprise in the United States and Europe: Understanding and Learning from the Differences. Voluntas: International Journal of Voluntary and Nonprofit Organizations, 17(3), 246. https://doi.org/10.1007/s11266-006-9016-2

Kotabe, M., Martin, X., \& Domoto, H. (2003). Gaining from vertical partnerships: Knowledge transfer, relationship duration, and supplier performance improvement in the U.S. and Japanese automotive industries. Strategic Management Journal, 24(4), 293-316. https:/doi. org/10.1002/smj.297

Leslie, S. W. (1993). The Cold War and American Science: The Military-industrial-academic Complex at MIT and Stanford. Columbia University Press.
Libecap, G. D., Thursby, M., \& Hoskinson, S. (Eds.). (2010). Spanning boundaries and disciplines: University technology commercialization in the idea age (1. ed). Bingley: Emerald.

Lin, M.-W., \& Bozeman, B. (2006). Researchers' industry experience and productivity in university-industry research centers: A "scientific and technical human capital" explanation. The Journal of Technology Transfer, 31(2), 269-290.

Link, A. N., Siegel, D. S., \& Bozeman, B. (2017). An empirical analysis of the propensity of academics to engage in formal university technology transfer. In Universities and the Entrepreneurial Ecosystem. Edward Elgar Publishing.

Link, A. N., Siegel, D. S., \& Van Fleet, D. D. (2011). Public science and public innovation: Assessing the relationship between patenting at US National Laboratories and the Bayh-Dole Act. Research Policy, 40(8), 1094-1099.

Lundquist, G. (2003). A rich vision of technology transfer technology value management. The Journal of Technology Transfer, 28(3-4), $265-284$.

MacCormick, N. (1998). Norms, Institutions, and Institutional Facts. Law and Philosophy, 17(3), 301. https://doi.org/10.2307/3504883

Marginson, S. (2011). Higher Education and Public Good. Higher Education Quarterly, 65(4), 411-433. https://doi.org/10.1111/j.14682273.2011.00496.x

Mazzucato, M. (2015). The entrepreneurial state: Debunking public vs. Private sector myths (Vol. 1). Anthem Press.

Metlay, G. (2006). Reconsidering renormalization: Stability and change in 20th-century views on university patents. Social Studies of Science, 36(4), 565-597.

Mowery, D. C., Nelson, R. R., Sampat, B. N., \& Ziedonis, A. A. (2001). The growth of patenting and licensing by US universities: An assessment of the effects of the Bayh-Dole act of 1980. Research Policy, 30(1), 99-119.

Mowery, D. C., Nelson, R. R., Sampat, B. N., \& Ziedonis, A. A. (2015). Ivory tower and industrial innovation: University-industry technology transfer before and after the Bayh-Dole Act. Stanford University Press.

Nakamura, R. T., \& Smallwood, F. (1980). The politics of policy implementation. New York: St. Martin's Press.

NASA. (1998). Communicating NASA's Knowledge: A report of the communicate knowledge process team. Washington, DC: U.S. Government Printing Office. Retrieved from U.S. Government Printing Office website: https://www.hq.nasa.gov/ckreport/

National Research Council. (1999). Funding a revolution: Government support for computing research. National Academies Press. 
National Science Foundation. (2014). Federal programs to promote technology transfer and the commercialization of federal R\&D. Science and Engineering Indicators 2014. Retrieved from Federal programs to promote technology transfer and the commercialization of federal R\&D. Science and Engineering Indicators 2014.

National Science Foundation. (2020). NSF I-Corps Home. Retrieved February 22, 2021, from NSF I-Corps website: https://www.nsf.gov/ news/special_reports/i-corps/index.jsp

Necoechea-Mondragón, H., Pineda-Domínguez, D., \& Soto-Flores, R. (2013). A Conceptual Model of Technology Transfer for Public Universities in Mexico. Journal of Technology Management \& Innovation, 8(4), 24-35. https://doi.org/10.4067/S0718-27242013000500003

Ortigueira-Sánchez, L. C., Stein, W. C., Risco-Martínez, S. L., \& Ricalde, M. F. (2020). The Impact of Absorptive Capacity on Innovation in Peru. Journal of Technology Management \& Innovation, 15(4), 19-29. https://doi.org/10.4067/S0718-27242020000400019

O’shea, R. P., Allen, T. J., Chevalier, A., \& Roche, F. (2005). Entrepreneurial orientation, technology transfer and spinoff performance of US universities. Research Policy, 34(7), 994-1009.

Oughton, C., Landabaso, M., \& Morgan, K. (2002). The regional innovation paradox: Innovation policy and industrial policy. The Journal of Technology Transfer, 27(1), 97-110.

Papadakis, M. (1994). Did (or does) the United States have a competitiveness crisis? Journal of Policy Analysis and Management, 13(1), 1-20.

Park, S.-H., \& Lee, Y.-G. (2011). Perspectives on Technology Transfer Strategies of Korean Companies in Point of Resource and Capability Based View. Journal of Technology Management \& Innovation, 6(1), 161-184. https://doi.org/10.4067/S0718-27242011000100013

Perkmann, M., Tartari, V., McKelvey, M., Autio, E., Broström, A., D’Este, P., ... Sobrero, M. (2013). Academic engagement and commercialisation: A review of the literature on university-industry relations. Research Policy, 42(2), 423-442. https://doi.org/10.1016/j. respol.2012.09.007

Phan, P. H., \& Siegel, D. S. (2006). The effectiveness of university technology transfer: Lessons learned from quantitative and qualitative research in the US and the UK. Rensselaer Working.

Powers, J. B. (2003). Commercializing academic research: Resource effects on performance of university technology transfer. The Journal of Higher Education, 74(1), 26-50.

Rahm, D., Bozeman, B., \& Crow, M. (1988). Domestic Technology Transfer And Competitiveness: An Empiri. Public Administration Review, 48(6), 969.

Rainey, H. G., \& Bozeman, B. (2000). Comparing public and private organizations: Empirical research and the power of the a priori. Journal of Public Administration Research and Theory, 10(2), 447-470.
Resnick, P. (2001). Beyond bowling together: Sociotechnical capital. HCI in the New Millennium, 77, 247-272.

Rogers, E. M., Carayannis, E. G., Kurihara, K., \& Allbritton, M. M. (1998). Cooperative research and development agreements (CRADAs) as technology transfer mechanisms. RઐD Management, 28(2), 79-88.

Rogers, E. M., Takegami, S., \& Yin, J. (2001). Lessons learned about technology transfer. Technovation, 21(4), 253-261.

Rothaermel, F. T., Agung, S. D., \& Jiang, L. (2007). University entrepreneurship: A taxonomy of the literature. Industrial and Corporate Change, 16(4), 691-791. https://doi.org/10.1093/icc/dtm023

Saavedra, P., \& Bozeman, B. (2004). The "Gradient Effect" in Federal Laboratory-Industry Technology Transfer Partnerships. Policy Studies Journal, 32(2), 235-252.

Sampat, B. N. (2006). Patenting and US academic research in the 20th century: The world before and after Bayh-Dole. Research Policy, 35(6), 772-789. https://doi.org/10.1016/j.respol.2006.04.009

Sanders, C. B., \& Miller, F. A. (2010). Reframing norms: Boundary maintenance and partial accommodations in the work of academic technology transfer. Science and Public Policy, 37(9), 689-701. https:// doi.org/10.3152/030234210X12778118264576

Schacht, W. H. (2012). Technology transfer: Use of federally funded research and development (CRS Report No. RL33527).

Siegel, D. S., Veugelers, R., \& Wright, M. (2007). Technology transfer offices and commercialization of university intellectual property: Performance and policy implications. Oxford Review of Economic Policy, 23(4), 640-660.

Sorensen, J. A. T., \& Chambers, D. A. (2008). Evaluating academic technology transfer performance by how well access to knowledge is facilitated--defining an access metric. The Journal of Technology Transfer, 33(5), 534-547.

Srivastava, P., \& Chandra, S. (2012). Technology Commercialization: Indian University Perspective. Journal of Technology Management \& Innovation, 7(4), 121-131. https://doi.org/10.4067/S071827242012000400010

Stevenson-Wydler Technology Innovation Act of 1980. , Pub. L. No. 96-480, 94 Stat. 23113701 (1980). (Codified at 15 USC 3701-3714)

Stoneman, P., \& Diederen, P. (1994). Technology diffusion and public policy. The Economic Journal, 104(425), 918-930.

Storey, D. J., \& Tether, B. S. (1998). Public policy measures to support new technology-based firms in the European Union. Research Policy, 26(9), 1037-1057.

Teece, D. J. (1977). Technology transfer by multinational firms: The resource cost of transferring technological know-how. The Economic Journal, 87(346), 242-261. 
U.S. Dept. of Health and Human Services [DHHS], Office of Inspector General. (1993). Technology transfer and the public interest: Cooperative research and development agreements at NIH (No. OEI01-92-01100).

U.S. DOE Office of Science. (2020, August 13). SBIR/STTR Phase III Success Stor... | U.S. DOE Office of Science(SC). Retrieved March 8, 2021, from https://science.osti.gov/sbir/SBIR-STTR-Phase-III-Success-Stories

U.S. White House, Office of the Press Secretary. (2011). Presidential Memorandum-Accelerating Technology Transfer and Commercialization of Federal Research in Support of High-Growth Businesses. Retrieved from https://obamawhitehouse.archives.gov/ the-press-office/2011/10/28/presidential-memorandum-accelerating-technology-transfer-and-commerciali
Winebrake, J. J. (1992). A study of technology-transfer mechanisms for federally funded R\&D. The Journal of Technology Transfer, 17(4), $54-61$.

Wright, M. (2014). Academic entrepreneurship, technology transfer and society: Where next? The Journal of Technology Transfer, 39(3), $322-334$.

Youtie, J., \& Shapira, P. (2017). Exploring public values implications of the I-Corps program. The Journal of Technology Transfer, 42(6), 1362-1376. https://doi.org/10.1007/s10961-016-9518-z

Zucker, L. G. (1988). Institutional patterns and organizations: Culture and environment. Ballinger Pub Co. 